\title{
INTRANASAL PREMEDICATION WITH DEXMEDETOMIDINE AND MIDAZOLAM IN OPHTHALMIC SURGERY FOR PEDIATRICS, ARE THEY REALLY EQUALLY EFFECTIVE?
}

\author{
By \\ Ghada F. Amer, MD* \\ Trom \\ *From Anesthesia and Surgical Intensive Care Department, \\ Faculty of Medicine, Mansoura University.
}

\begin{abstract}
Introduction: Excessive anxiety has a bad implication on anesthetic practice in pediatric anesthesia, that is why to decrease anxiety by premedication is an important issue. Intranasal administration of various drugs is an easy route with rapid onset of action allowing administration of a variable drugs such as Midazolam and Dexmedetomidine used in pediatric preoperative sedation.
\end{abstract}

Methodology: 64 children who were submitted for elective ophthalmic surgeries received either $0.5 \mathrm{mg} /$ $\mathrm{kg}$ midazolam or $1 \mu \mathrm{g} / \mathrm{kg}$ dexmedetomidine intranasally. Basal heart and respiratory rate, blood pressure, sedation score and oxygen saturation were recorded initially and every 5 minutes till the transfer to the operating room. Sedation score was also assessed at 30 minutes after drug administration. Postoperative monitoring was continued and any postoperative complications were recorded.

Results: Oxygen saturation, heart rate, systolic blood pressure and respiratory rate values showed insignificant differences when both groups were compared together, but showed significance differences when compared with the basal value in each group separately after 30 
minutes. Sedation score was faster and child-parents separation score was higher in dexemedetomidine group when compared with midazolam group, also both groups showed significant sedation score less than 3 when compared with the basal value at $15,20,25,30$ minutes .

Conclusion: Midazolam and dexmedetomidine were nearly equally effective as intranasal premedication for pediatric patients submitted for ophthalmic surgery with minimal side effects and we recommend the use of midazolam due to its safety and effectiveness and low price.

Key words: Premedications, Intranasal route, Midazolam, Dexmedetomedine, Sedation, Separation, Scoring.

\section{INTRODUCTION}

Excessive anxiety has a bad implication on anesthetic induction and recovery in pediatric anesthesia and usually leads to functional and psychological disability after surgery $(1)$. Premedication in pediatric patients has a great role in releasing anxiety and psychological trauma which represent a great challenges in pediatric anesthesia(2).

Vol. 43, No. 1 \& 2 Jan. \& April, 2014
Pediatric patients premedication using intranasal route has been proved by multiple studies as an effective and safe way $(3,4)$. Intranasal administration of various drugs is an easy, non invasive route with high bioavailability and rapid onset of action due to high blood supply of the upper airway mucosa and escaping from the first pass metabolism(5).

Midazolam which is a shortacting benzodiazepine, with short elimination half life and anterograde amnesic effect, represents a widely used drug in preanesthetic anxiolysis and sedation ${ }^{(6)}$. Like midazolam but with selective agonist action on alpha 2 adenoceptor, Dexmedetomidine represents a new anesthetic premedication drug with a shorter duration of action $(7,8)$.

The aim of this study is to compare the efficacy of dexmedetomidine versus midazolam as sedative premedication drugs given by intranasal route in pediatric patients undergoing elective ophthalmological surgical procedures.

\section{Patients}

This double blinded comparative study was conducted in Mansoura 
University Ophthalmology Center, over six months, after obtaining our Institutional Research Board (IRB) approval and an informed written consents from all patient guardians.

\section{Inclusion criteria:}

1. Patients who were submitted for elective ophthalmic surgery.

2. ASA ?, ?.

3. Age: 2-6 years.

\section{Exclusion criteria:}

1. Parent refusal.

2. Patients suffering from congenital cardiac disease.

3. History of allergy to any of the studied drugs.

4. Any nasal disorders that may hinder nasal administration of the drugs as repeated nasal bleeding or nasal tumors.

\section{MATERIAL \& METHODS}

Patients were allocated into two groups using closed envelops randomization method (32 each): intranasal midazolam group ( $M$ group): in which patients were given $0.5 \mathrm{mg} /$ $\mathrm{kg}$ midazolam. And Intranasal dexmedetomidine group (D group): in which patients received $1 \mu \mathrm{g} / \mathrm{kg}$ dexmedetomidine .
In the preoperative room, medications were given 30 minutes prior to anesthesia with attendance of one of the patient's parents. Intranasal drug were given into the infants nose using a 3-ml syringe in the recumbent position as nasal drops over 5 minutes. Basal heart and respiratory rate, blood pressure, and oxygen saturation were recorded initially and every 5 minutes after giving the intranasal drug for 30 minutes till being transferred to the operating room $(\mathrm{OR})$. Sedation assessment was carried out every $5 \mathrm{~min}$ for 30 minutes from giving the drug, using a 4 point scale Sedation level: Agitated $=4$, awake=3, drowsy=2, asleep=1 (8). Sedation score of 1 or 2 will be considered satisfactory, sedation score of 3 or more was considered unsatisfactory. Child patient response for separation from the guardian was assessed at 30 minutes using a 4 point scale Separation score: patient unafraid, cooperative, sleep $=1$, slight fear or crying, quite with reassurance $=2$, moderate fear or crying not quite with reassurance $=3$, crying need for restrained $=4$. $(8)$

On arrival at the operative room, monitoring equipment including ECG, NIBP and $\mathrm{SpO}_{2}$ were connect-

MANSOURA MEDICAL JOURNAL 
ed to the patient. Sevoflurane 5\% and oxygen $100 \%$ were used to induce anesthesia via a facemask, then an intravenous line was fixed in place, then patient airway was secured using an appropriate size of laryngeal mask airway (LMA) and the patient was left to breathe spontaneously after decreasing $\mathrm{FiO} 2$ to $50 \%$. A suitable concentration was employed to facilitate the surgical procedure and maintain stabilization of heart rate, blood pressure and respiratory rate (basal $\pm 20 \%$ ). At the end of the surgical procedure, anesthesia was discontinued and $100 \%$ oxygen (4 liter/min) was continued till removal of LMA when the patient gained consciousness. Postoperative monitoring was continued after transfer of the patient to the recovery room with recording of any postoperative complications or untoward events as nausea, vomiting, increased secretions and / or bradycardia.

\section{Sample size}

Sample size was done, based on degree of sedation. Mann-Whitey U-test was used for comparison and setting alpha to 0.05 . This study needed at least 29 cases in each group to detect the same difference with $80 \%$ power. So we increased the number of cases to 32 cases in each group to compensate for any possible dropouts. PS software Windows was used for calculations.

\section{Statistical analysis:}

Data were first tested for normality by means of the Kolmogorov-Smirnov test. Normally distributed continuous data were analyzed using the Student t-test. Abnormal distributed continuous and or dinal data were analyzed using the Mann-Whitey U-test. Categorical data were analyzed by means of Fisher's exact test as appropriate. The results were presented as mean (SD), median and range or number and percentage of patients as appropriate. A $P$ value less than 0.05 was considered statistically significant. Statistical analyses were performed using IPM SPSS for Windows, version 18(IPM SPSS Inc., Chicago, Illinois, USA).

\section{RESULTS}

Intranasal route was used for premedication of 64 patients, and their demographic data were comparable in both groups(Table1).

Oxygen saturation values showed 
insignificant differences when both tion score( less than 3 after 10 minstudied groups were compared to- utes) than that of midazolam group, gether and when their values were after that sedation score in both compared with the basal one in each groups had comparable values. Also individual group (Figure 1). Although both groups showed significant seheart rate, systolic blood pressure dation score less than 3 when comand respiratory rate values showed no significant statistical difference when both groups were put in comparison together, they showed significance differences when compared to the basal value in each group separately at 30 minutes interval (Figure 2, 3, 4 respectively).

Patients who were premedicated with dexemedetomidine had achieved a significantly faster sedapared to the basal value at 15,20,25,30 minutes interval (Figure $5)$.

Children in dexemedetomidine group had achieved significant high child-parents separation score grade 1 in comparison to midazolam group (Figure 6).None of the children in both groups had significant incidence of nausea, vomiting or bradycardia.

Table (1): Patient demographic data of the studied groups, data are expressed as number and mean $\pm \mathrm{SD}$.

\begin{tabular}{|c|c|c|}
\hline & $\begin{array}{c}\text { Midazolam group } \\
\qquad(n=32)\end{array}$ & $\begin{array}{l}\text { Dexmedetomidine group } \\
\qquad(n=32)\end{array}$ \\
\hline Age (years) & $4.14 \pm 0.44$ & $4.01 \pm 0.40$ \\
\hline Gender (no) Male & 18 & 15 \\
\hline Female & 14 & 17 \\
\hline Weight $(\mathrm{Kg})$ & $16.32 \pm 4.27$ & $15.75 \pm 4.31$ \\
\hline
\end{tabular}


INTRANASAL PREMEDICATION etc...

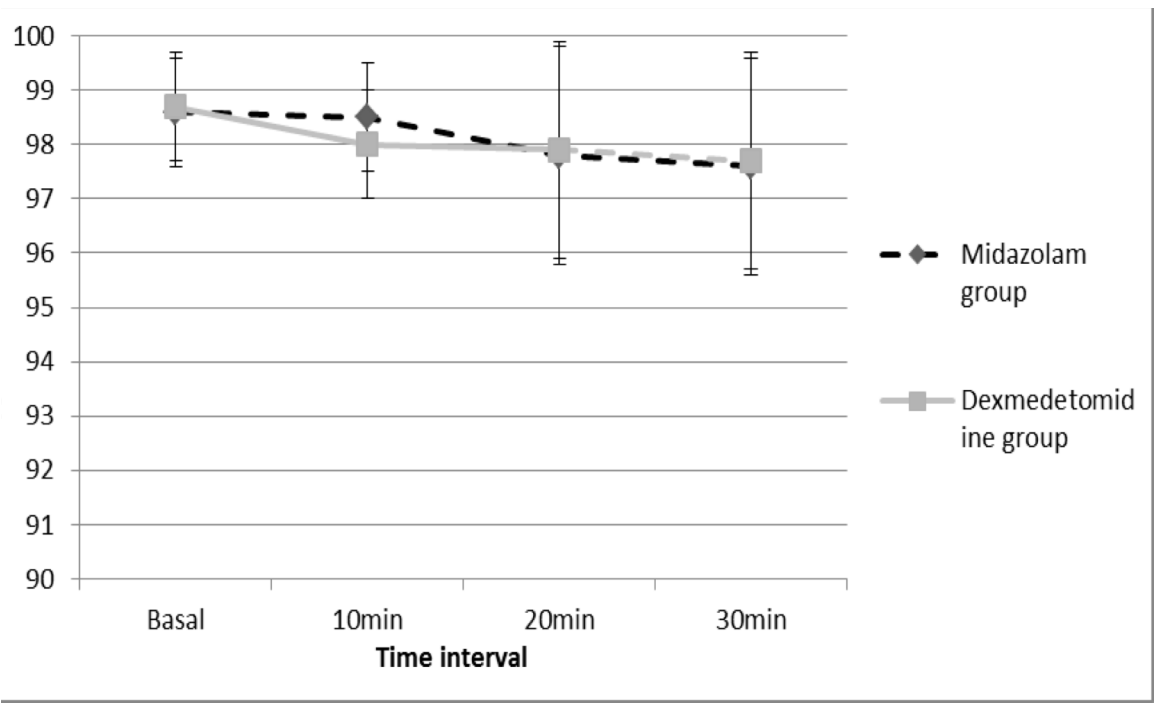

$* \mathrm{P}<0.05$ significant when compared with basal value.

Figure (1): Peripheral oxygen saturation of the studied groups, data are expressed as \%.

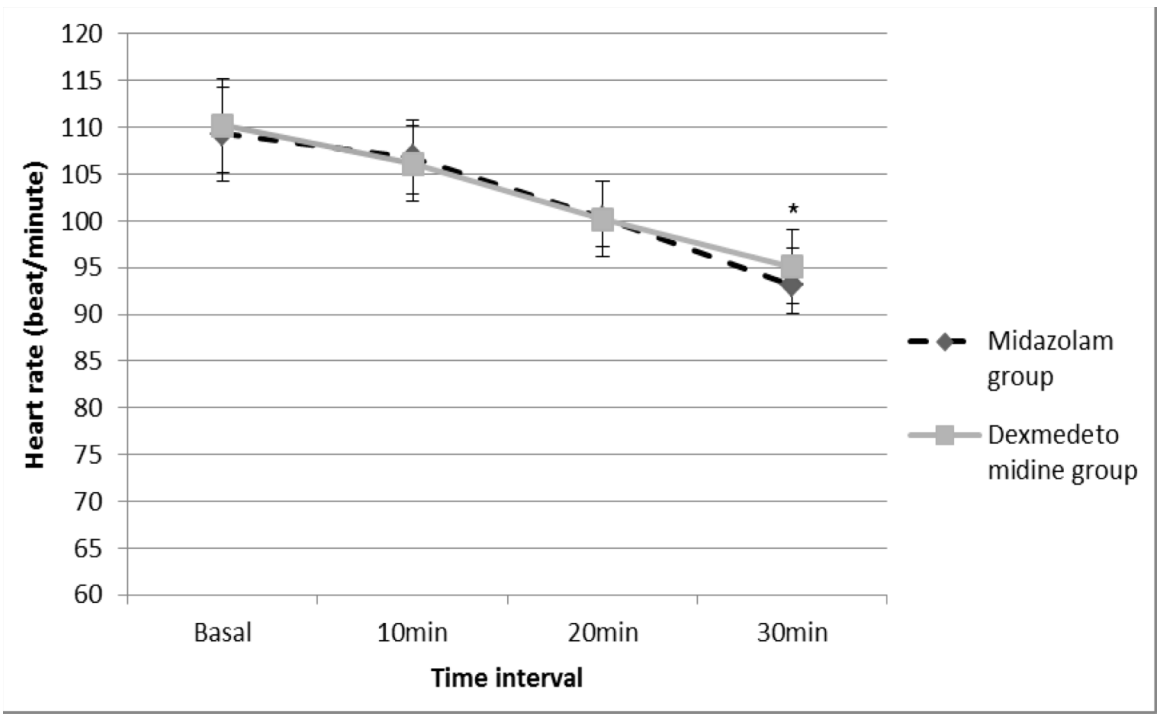

$* \mathrm{P}<0.05$ significant when compared with basal value.

Figure (2): Heart rate changes of the studied groups, data are expressed as mean \pm SD.

Vol. 43, No. 1 \& 2 Jan. \& April, 2014 


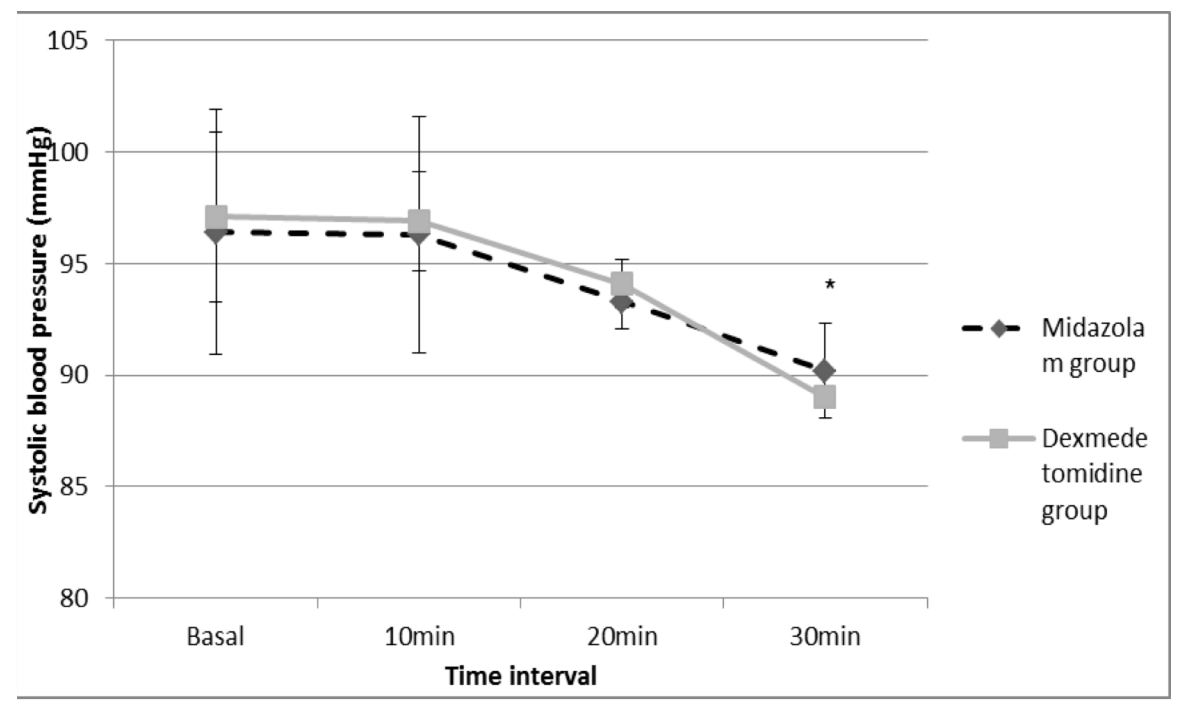

$* \mathrm{P}<0.05$ significant when compared with basal value.

Figure (3): Systolic blood pressure changes of the studied groups, data are expressed as mean \pm SD.

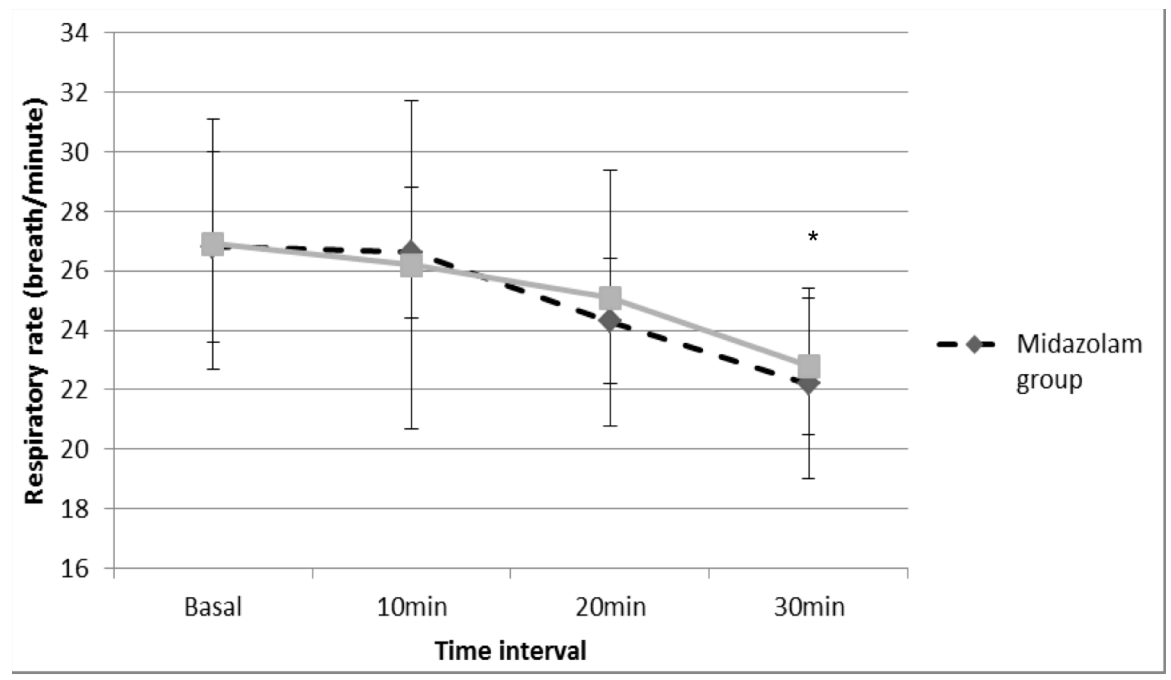

$* \mathrm{P}<0.05$ significant when compared with basal value.

Figure (4): Respiratory rate changes of the studied groups, data are expressed as mean $\pm S D$. 


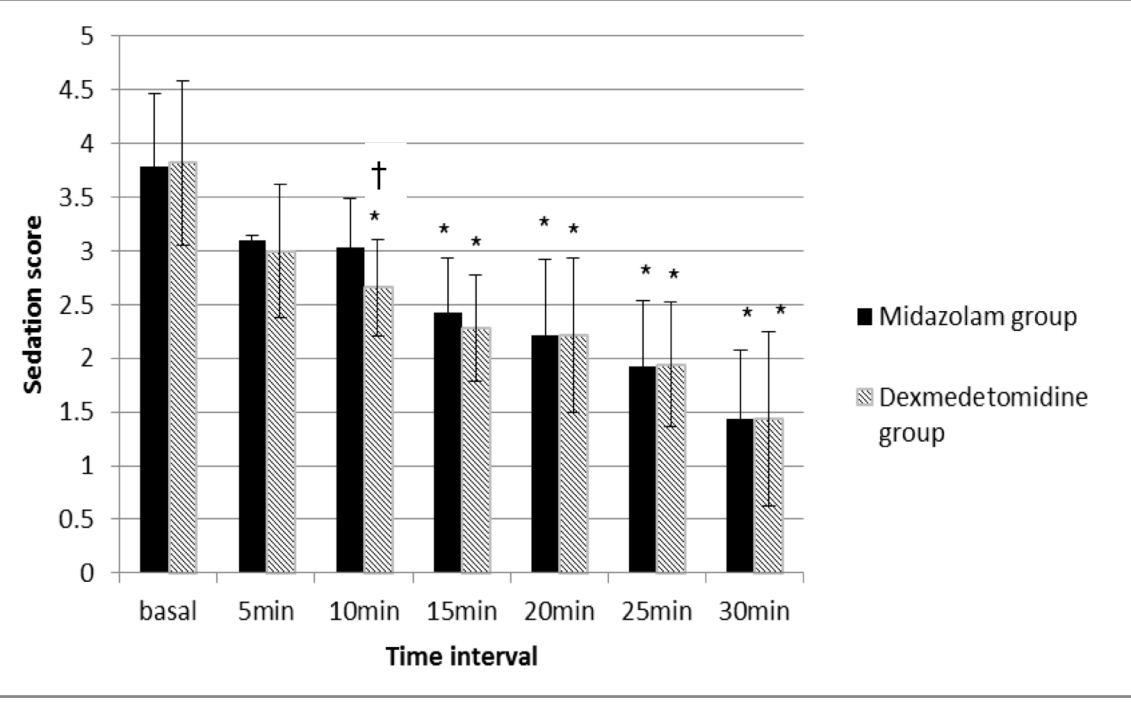

$* \mathrm{P}<0.05$ significant when compared with basal value.

$† \mathrm{P}<0.05$ significant when compared to Midazolam group.

Figure (5): Sedation score of the studied groups, data are expressed as mean \pm SD.

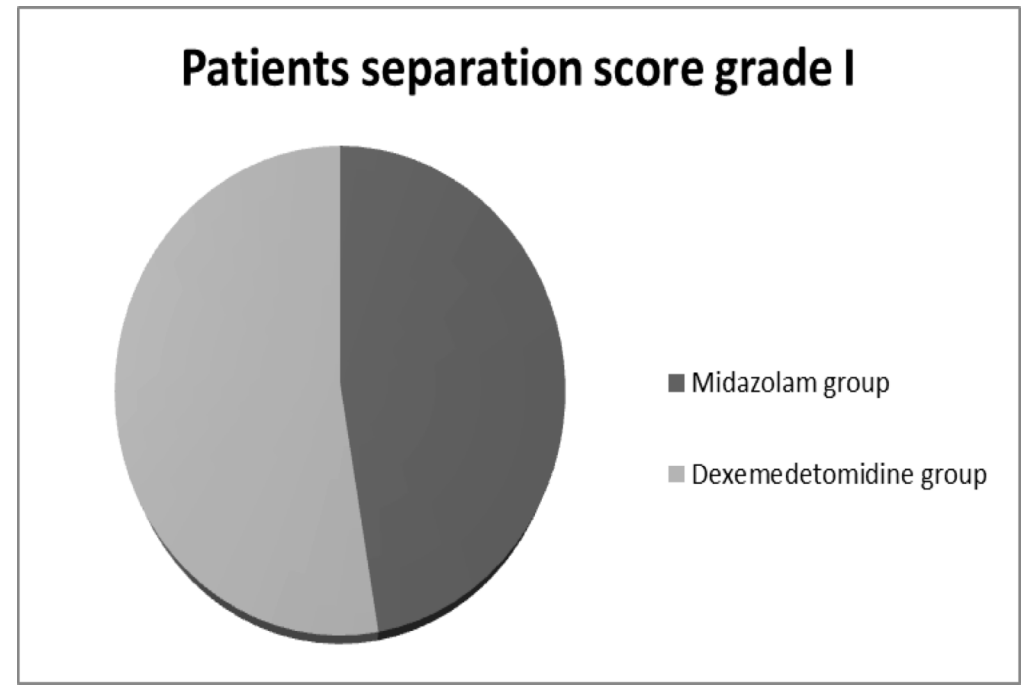

Figure (6): Patients separation score grade I of the studied groups.

Vol. 43, No. 1 \& 2 Jan. \& April, 2014 


\section{DISCUSSION}

Children in operative theaters are often uncooperative and anxious, this may be attributed to pain anticipation, strange environment, parental separation, or a previous fearful experience ${ }^{(9)}$. Perioperative anxiety is associated with an increased level of postoperative pain ,stress hormones release with negative outcomes, postoperative maladaptive behaviors like eating problems, night mars, enuresis, increased fear of doctors and hospitals $(7)$.

Sedative premedications have a great role in pediatric anesthesia but still the route of administration represents great obstacle in pediatric anesthesia. Because of that anesthetists try to find an effective, easy and applicable route for drug administration in pediatric patients. Drug injection by various routs is effective and reliable but very painful and leaves bad memories in children mind. Intranasal drug administration has been proved to be an effective convenient route for preoperative sedative drug administration in children. This may be attributed to its high bioavailability, simplicity of administration and being non-invasive, however cooperation is still required and some difficulty still present in younger children(10). Also, the high vascularity of the subepithelial surface of the nasal cavity facilitates the access of the drugs to the systemic circulation bypassing the first-pass metabolism in the liver (11).

Currently, the most commonly used sedative premedications include midazolam and dexmedetomedine. Midazolam has great efficacy when given intranasally but it is associated with unpleasant burning sensation in the nasal cavity that may not favoure its use in practice. However, other studies reported that intranasal administration of midazolam is better tolerated by infants and has higher plasma concentration in comparison to its oral administration $(12,13)$.

Another widely used preanesthetic medication drug is dexmedetomidine which is an alpha 2adrenoreceptor agonist, that has sedative, analgesic and anxiolytic effects via activation of central alpha 2-adrenoreceptors in the locus ceruleus approximately eight times that of clonidine (14). Intranasal administration of dexmedetomidine produced a clinical sedative effect last-

MANSOURA MEDICAL JOURNAL 
ing for more than 180 minutes. Two recent studies have reported clinically significant sedative effects when dexmedetomidine was administered intranasally to healthy adult volunteers and to children undergoing minor surgery $(12,14)$.

This current study tried to compare the effects of both dexmedetomidine and midazolam given intranasally on satisfactory sedation and separation from parents in children aged between 2 and 8 years undergoing elective surgery, as this age is most suspected to separation anxiety and their understanding and cooperation is limited.

This study showed that patients oxygen saturation did not decrease with either intranasal midazolam or dexmedetomidine, this means that both drugs has no adverse implication on patient's oxygenation.

Children who were premedicated with $1 \mu \mathrm{g} / \mathrm{kg}$ of dexemedetomidine had achieved a significantly faster and satisfactory sedation score (less than 3 after 10 minutes) than those premedicated with $0.5 \mathrm{mg} / \mathrm{kg}$ of midazolam, after that sedation score in both groups had comparable values.
Children in dexmedetomidine group had achieved higher child-parents separation score grade 1 in comparison with midazolam group.

The minimal variation in the onset of sedation between midazolam and dexemedtomidine may be due to the same site and mechanism of action of both drugs, both drugs act on the central nervous system in locus ceruleus with electroencephalogram activity similar to natural sleep (15).

This results was similar to those proved by Naill et al(5) McCormick et al, who found that $0.2 \mu \mathrm{g} / \mathrm{kg}$ intranasal midazolam premedication is a rapid and effective method of sedation in children $\left({ }^{16)}\right.$, also Lejus et al (17) reported that intranasal midazolam is an effective route of premedication although it is poorly accepted by some patients. Also Vivian et al (18) and Cheung et al(19) in their studies showed that intranasal dexmedetomidine $1 \mu / \mathrm{kg}$ as premedication was effective as sedation for patients undergoing third molar surgery under local anesthesia with better postoperative pain relief and no delay in pschychomotor recovery .

Ashu et al (20) reported that intra- 
nasal midazolam produced more rapid onset of sedation (average 4.8 minutes) and time of maximal sedation was only 12.7 minutes which is not in agreement with our results. This difference may be due to age group of his study started from 6 month up to 6 years and different dose used .

When comparing both drugs together as regard sedation we found that dexmedetomedine produces more rapid onset of sedation but midazolam has more satisfactory sedative effects, this may matche the results obtained by Aynur Akin et al (21) that Intranasal dexmedetomidine and midazolam are equally effective in decreasing anxiety upon separation from parents; however, midazolam is superior in providing satisfactory conditions during mask induction. But may be different from another study by AL Meenakshi Sundaram et al (22) that Children premedicated with intranasal dexmedetomidine attained more significant and satisfactory sedation than those patients who received intranasal midazolam. The sedation produced by dexmedetomidine differs from other sedatives as patients may be easily aroused and cooperative .
Our results showed that there was statistically significant change in systolic blood pressure, heart rate and respiratory rate in both groups after 30 minutes when compared with the basal values, with no difference between both groups. This may be due to increase level of sedation and reduction in sympathetic outflow and circulating level of catecholamines and this matches previous studies by Remadevi et al(23), and Talke et al (24) who reported that intranasal dexmedetomidine reduces heart rate and systolic blood pressure during the preoperative sedation .

In summary, $1 \mu / \mathrm{kg}$ intranasal dexmedetomidine produces significant sedation in children between 2 and 6 years of age. Behavior of the children at parental separation and at induction of anesthesia was comparable to children who received midazolam. The hemodynamic effects of intranasal dexmedetomidine were modest

We concluded that both midazolam and dexmedetomidine are nearly equally effective as intranasal premedication for pediatric patients with minimal side effects. Dexemedetomi-

MANSOURA MEDICAL JOURNAL 
dine produced 5 minutes earlier onset of sedation than midazolam through intranasal route however midazolam was equally effective after that with dexmedetomidine as regards sedation score, parent child separation score. Considering the high cost of using dexmedetomidine as premedication we prefer the use of midazolam due to its safety and effectiveness as well as availability and low price compared with dexemedetomidine.

\section{REFERENCES}

(1) Sun GC, Hsu MC. (2008) : Effects of age and gender on intravenous midazolam premedication: a randomized double-blind study. British journal of Anesthesia; 101:632-5.

(2) Morgan JO, Bangham JA. (1990) : Preinduction behavior of children. Anesthesia; 45:427-35.

(3) Wang J, Bru G. (2002) : Influence of intranasal medication on the structure of the nasal mucosa. China Med J; 115(4):617-9.
(4) Abrams R, Morrison JE, Villassenor A. (1993) : Safety and effectiveness of intranasal administration of sedative medications for urgent brief pediatric dental procedures. AnesthProg; 4:63-6.

(5) Wilton NCT, Leigh J, Rosen DR, Pandit UA. (1988) : Preanesthetic sedation in preschool children by using intranasal midazolam. Anaesthesiology ; 69:972-5.

(6) Dundee JW, Wilson DB. (1980) : Amnesic action of midazolam. Anaesthesia, 35: 459-61.

(7) Schmidt AP, ValinettiEA, Banderira D, Bertacchi MF, Simoes CM, Auler JO JR. (2007) : Effects of preanesthetic administration of midazolam, clonidine, or dexmedetomidine on postoperative pain and anxiety in children. Pediatric Anesthesia; 17: 667-74.

(8)Yuen VM, Hui TM, Yuen MK, Yuen MK, Lee LH. (2007) : 
A double blind crossover assessment of the sedative and analgesic effects of intranasal dexmedetomidine. AnesthAnalg; 105:374-80.

(9)Chhibber A, Fickling K, Lustik S. (2011) : Pre-Anesthetic Midazolam: A Randomized Trial with Three Different Routes of Administration. Journal Anesthesia Clinic Res, 2:1.

(10) Talgaonkar S, Mishra PR. (2004) : Intranasal delivery: an approach to bypass the blood brain barrier. Indian Journal of Pharmacology 36: $140-7$.

(11) Turker S, Onur E, Ozer Y. (2004) : Nasal route and drug delivery systems. Pharmacology World Science 26: 137-42.

(12) Yuen VM, Irwin MG, Hui TW, Yuen MK, Lee LH. (2007) : A double-blind,crossover assessment of the sedative and analgesic effects of intranasal dexmedetomidine.
Anesthesia Analgesia; 105: 374-80.

(13)Yildirim SV, Guc BU, Bozdogan N, Tokel K. (2006) : Oral versus intranasal midazolam premedication for infants during echocardiographic study. AdvTher; 23: 719-724.

(14) Yuen VM, Hui TW, Irwin MG et al. (2008) : A comparison of intranasal dexmedetomidine and oral midazolam for premedication in pediatric anesthesia: a double-blinded randomized controlled trial. Anesthesia Analgesia; 106: 1715-6.

(15) Khan ZP, Ferguson CN, Jones RM. (1999) : Alpha-2 and imidazoline receptor agonists. Anesthesia; 54:14665.

(16) McCormick AS,Thomas VL,Berry D, Thomas PW. (2008) : Plasma concentrations and sedation scores after nebulized andintranasal midazolam in

MANSOURA MEDICAL JOURNAL 
healthy volunteers.British Journal of Anaesthesia; $100(5): 631-6$.

(17) LejusC, RenaudinM, Testa S, Malinovsky JM, Vigier T, Sowon R. (1977) : Midazolam for sedation in children nasal versus rectal administration. Eur $\mathrm{J}$ Anaethesia;14:244-9.

(18) Cheung WC, Ng GF, Yeun MY, Ho M H, Irwin MG. (2011) : Analgesic and sedative effects of intranasal dexmedetomidine in third molar surgery under local anesthesia.British Journal of Anesthesia; 107(3): 430-7.

(19 Vivian M, Hui W, Irwin G, Yuen MK. (2008) : A comparison of intranasal dexemedetomidine and oral midazolam for premedication in pediatric anesthesia: a double blinded randomized controlled trial. Anesthesia Analgesia; 106:1715-21.

(20) Mathai A, Nazareth M, Raju R. (2011) : Preanesthetic se- dation of preschool children: comparison of intranasal midazolam versus oral promethazine. Anesthesia :Essays and Researches; 5(1);67-4.

(21) Akin A, Bayram A, Esmaoglu A, Tosun Z, Aksu R, Altuntas $R$, Boyaci A. (2012) : Dexmedetomidine versus midazolam for premedication of pediatric patients undergoing anesthesia. Pediatric anesthesia; 22( 9); 871-5.

(22) Sundaram AL, Mathian V M. (2011) : A Comparative Evaluation of Intranasal Dexmedetomidine and Intranasal Midazolam for Premedication in Children : A Double Blind Randomised Controlled Trial. JIDA; 5 (7); 777-4.

(23) Remadev P, Chandrasekar L, Vasudevan A. (2009) : Comparison of midazolam and ketamine as oral premedicants in pediatric patients. Internet Journal of Anesthesiology; 2 1:2. 
(24) Talke P, Chen R, Thomas B, Aggarwall A, Gottlieb A, Thorborg P, Heard S, Cheung A, Son SL, Kallio

A. (2000) : The hemody- namic andadrenergic effects of perioperative dexemdetomidine infusion after vascular surgery. Anesthesia Analgesia: 90:834-9. 


$$
\text { الملحخص العربى }
$$

\title{
التخدير عن طريق الانف باستخدام عقارى الديكسيهيد
}

\section{يتوميدين والميدازولام فى جراحات العيون بالاطفال.}

\section{هل هما على نفس القلدر من الفاعليه؟}

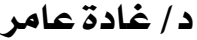

، كلية الطب ، جامعة المنصورة

$$
\text { قسيم }
$$

القلق الزائد له تاثير سئ على بداية تخدير الاطفـال والافاقة من التخدير الكلى وعادة مـا يؤدى الى اعاقة وظيفية ونفسية بعد الجراحة .فاعطاء علاج دواء ما قبل الجـراحة له دور كبير فى ازالة القلق و الصدمة النفسيه والتى تمثل تحدى كبير فى تخدير الاطفـال .وقد اثبتت الدراسات ان تخدير الأطفال المرضى باستخدام طريق داخل الأنف هى وسيلة فعالة وآمنـة .تعاطى العلاج عن طريق داخل الانف طريقة سهلـة وفعـالة وامنـة مـع زيـادة التوافر البيولوجي وبـايـة سـريعة للعمل بسبب ارتفاع تدفق الدم فى الغشاء المخاطى للمجرى الهواء العلوى والهروب من المرور خلال أول الأيض. يعتبر الميدازولام هو البنزوديازيبين قصير المفعول، مع نصف العمر القصير.يستخدم الميدازولام على نطاق واسع فى تهدئة قلق مـا قبل التخـدير. يعتبـر الديكسيميديتوميدين مثل الميدازولام ولكن مح تاثير انتقائى على مستقبلات الفا 2 الادرينية.يمثل الديكسيميديتوميدين عقار تخدير جديد مـع مدة عمل اقصر. هذه الدراسة محاولة لتقييم فعاليـة ديكسميديتوميدين وميدازولام باعتبارها عقاقير تخدير مهدئة باستخدام طريق داخل الأنف فى الأطفال المرضى وهم يخضعون للإجراءات الجراحية الاختيارية. اجريت الدراسة فى مـركز طب وجراحة العيون بجامعة المنصورة وتم تقسيم الاطفـال المرضى 
الى مجـموعتين بـاستخــام طريقة المظروف المغلق العشـوائيـة كل مـجموعـة تتكون من 32 حالهـ.

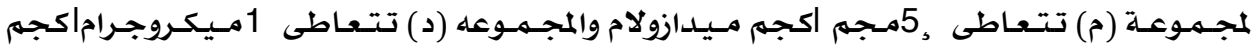
ديكسيميديتوميدين عن طريق الانف قبل الجراحة ب 30 دقيقـة.ثم يتم تقييهم سكون المرضي من خلال مقياس السكون. ثم يتم تخدير الحالات باستخدام القناع الوجهى باستخدام السيفوفلورين. ويتم اثنـاء الجراحسة مـراقبـة وتسـجيل العلامـات الحيـويـة للـمرضى مـن حـيث ضغط الدم وضـربات القلب ونسبة الاوكسجين فى الدم.

اثبتت هذه الدراسـة انه عند مقارنة كل من عقارى الديكسيميديتوميدين مـع الميدازولام لتهـئهـ الاطفـال قبـل العـمليـات الجـراحيـة عن طريـق الانف تبـين ان الميـدازولام له تاثيـر اكثر سـرعة ولهـ تاثيرات مهدئة متقارية مـع تلك النتائج التى حصلنـا عليها من الديكسيميديتوميدين. لهذايفضل الميدازولام عن الديكسيميديتوميدين نظرا لقلة سعره وتوافره اكتر مـن الديكسيميديتوميدين. 